\title{
The Behavior of Alternative Kacapuri Foundation on Alluvial Land of Central Borneo
}

\author{
Muhammad Afief Ma'ruf ${ }^{1, *}$, Ulfa Fitriati $^{1}$, and Lailan Ni'mah ${ }^{2}$ \\ ${ }^{1}$ Program Study of Civil Engineering, University of Lambung Mangkurat. A. Yani Road Km. 35,5, \\ Banjarbaru, Indonesia \\ ${ }^{2}$ Program Study of Chemical Engineering, University of Lambung Mangkurat. A. Yani Road Km. \\ 35,5, Banjarbaru, Indonesia
}

\begin{abstract}
One of the traditional substructure forms of Borneo is the kacapuri foundation. Previous research conducted a study on this kacapuri foundation by making an alternative kacapuri foundation model by combining a raft of gelam wood with reinforced concrete pillars. The study was originally applied to peat soil, but in reality, the kacapuri foundation was applied to alluvial soils around riverbanks rather than on peatlands. Therefore, this study looks at how the behavior of bearing capacity of the foundation when it is applied on alluvial soil. The location of the study where is located in the traditional Dayak Ngaju tribe in Mandomai village, Central Kalimantan. As a reference the application of the form of foundation using the model of Dayak house Huma Hai in the form of a house on stage with the main material of ironwood. The burden of each column of the house is $9,93 \mathrm{kN}$ in the middle pole position. From the research, it is found that the ultimate bearing capacity is $298 \mathrm{kN} / \mathrm{m} 2$, with its own weight is $4,816 \mathrm{kN}$.
\end{abstract}

\section{Introduction}

In South Borneo, which is a tropical region with many forests, the availability of various types of wood affects traditional building materials that exist. Then the type of soil in South Borneo that tend to swamp influence the form of foundation. In the area, the river is a very important means of communication and transportation. This caused so many buildings built along the river at that time. Given that riparian areas have a low and aqueous soil type, they must have a firm foundation to support the building above them.

The traditional foundation is usually used ironwood and gelam wood that existed throughout Borneo. The traditional substructure forms of Borneo community are ironwood pile foundation, gelam wood pile foundation, big stem foundation, and kacapuri foundation. Kacapuri foundation itself is a combination of ironwood pile foundation which is supported by a number of gelam wood in form of a raft. Ma'ruf, M. A., et al (2013) [1] conducted a study on this kacapuri foundation by making an alternative kacapuri foundation model by combining a raft of gelam wood with reinforced concrete pillars. This

\footnotetext{
Corresponding author: afief.maruf@ulm.ac.id
} 
alternative design is made because ironwood becomes rare nowadays in the market so it is replaced with a concrete pillar. Gelam wood itself has a special nature so it is very fitting to be part of the foundation of house building along the river bank. The nature of gelam wood is when it is submerged then its strength becomes durable and increase. Gelam wood that is submerged in the swamp continuously has power for tens of years.

The alternative kacapuri foundation research by Ma'ruf, M. A., et al (2013) [1] was investigated for application on stabilized peat soil. but in reality, the kacapuri foundation is more applied to alluvial soil. Therefore, this study looks at how the behavior of bearing capacity of the foundation when it is applied on alluvial soil

\section{Methodology}

The study conducted is located in the traditional Dayak Ngaju tribe in Mandomai village, Central Borneo. As a reference, the application of the form of foundation using the model of Dayak house Huma Hai in the form of a house on stage with the main material of ironwood, based on the research by The Ministry of Public Work (2015) [2]. There are 2 (two) research stages conducted in this research. The first is to do the Dutch Cone Penetration Test (CPT) located in Mandomai Subdistrict, Pulang Pisau District, Central Borneo in the area as shown in Figure 1. In this case, the soil samples that were tested in the laboratory show that the soil type is alluvial soil, but for the bearing capacity analysis in this research will only use the CPT data.

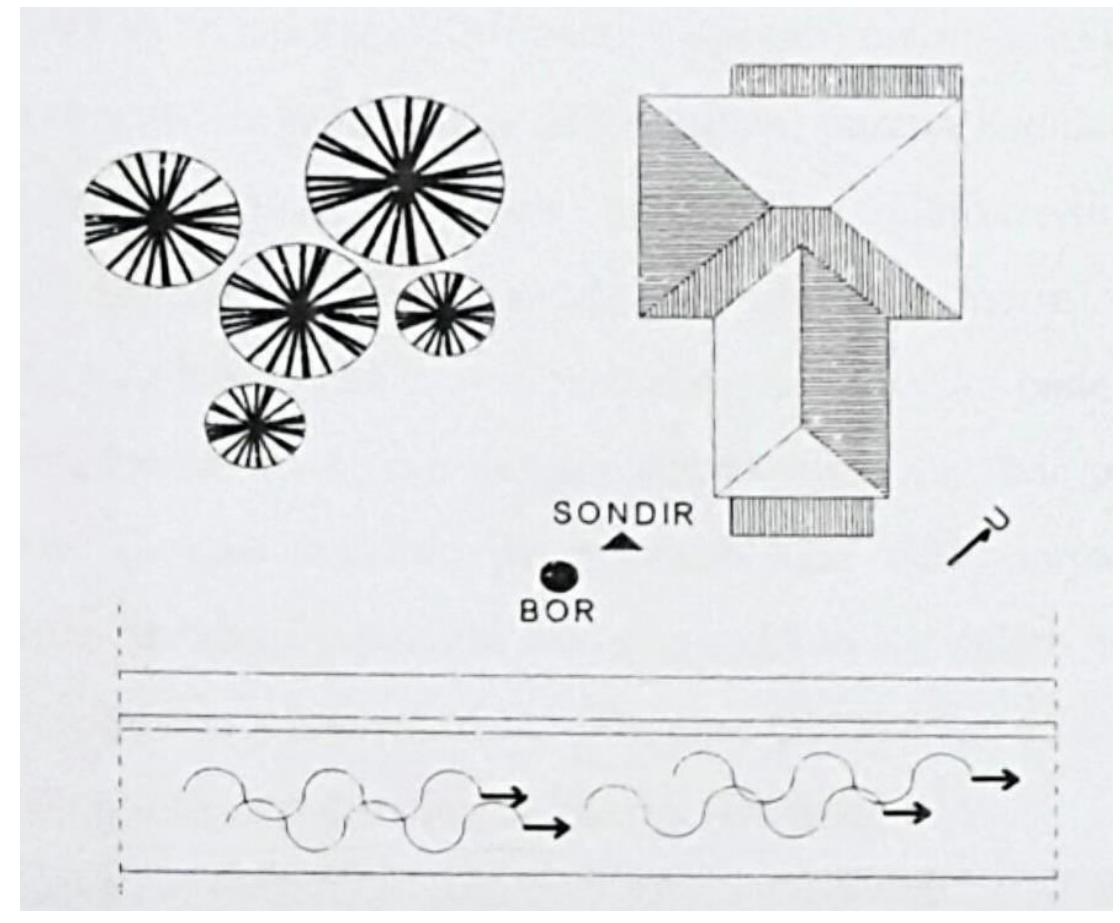

Fig. 1. The Location of CPT Test (Sondir) (The Ministry of Public Work 2015)

The next step is to calculate the soil bearing capacity for the alternative kacapuri foundation and the maximum load for the house model and the weight of the foundation itself. The alternative model of foundation uses the model with crossing 6 gelam wood rods 
as a raft or called Kacapuri 3 galam foundation according to Ma'ruf, MA, et al (2013) [1] research as can be seen in Figure 2. The length of the galam pole used is $4 \mathrm{~m}$ with a diameter of $8 \mathrm{~cm}$. Ironwood sheath $5 / 7$ along $4 \mathrm{~m}$, with $15 / 15$ concrete pillar as high as 2 $\mathrm{m}$. The foundation is designed embedded in the ground as deep as $1,5 \mathrm{~m}$. The approach to calculating the carrying capacity of its own soil according to Iskandar (2000) [3] is considered to behave like a continuous foundation with the length of the foundation is the length of the galam pole used. In this case, the CPT data is used with Bowles's (1997) [4] continuous foundation equation as can be seen in equation (1).

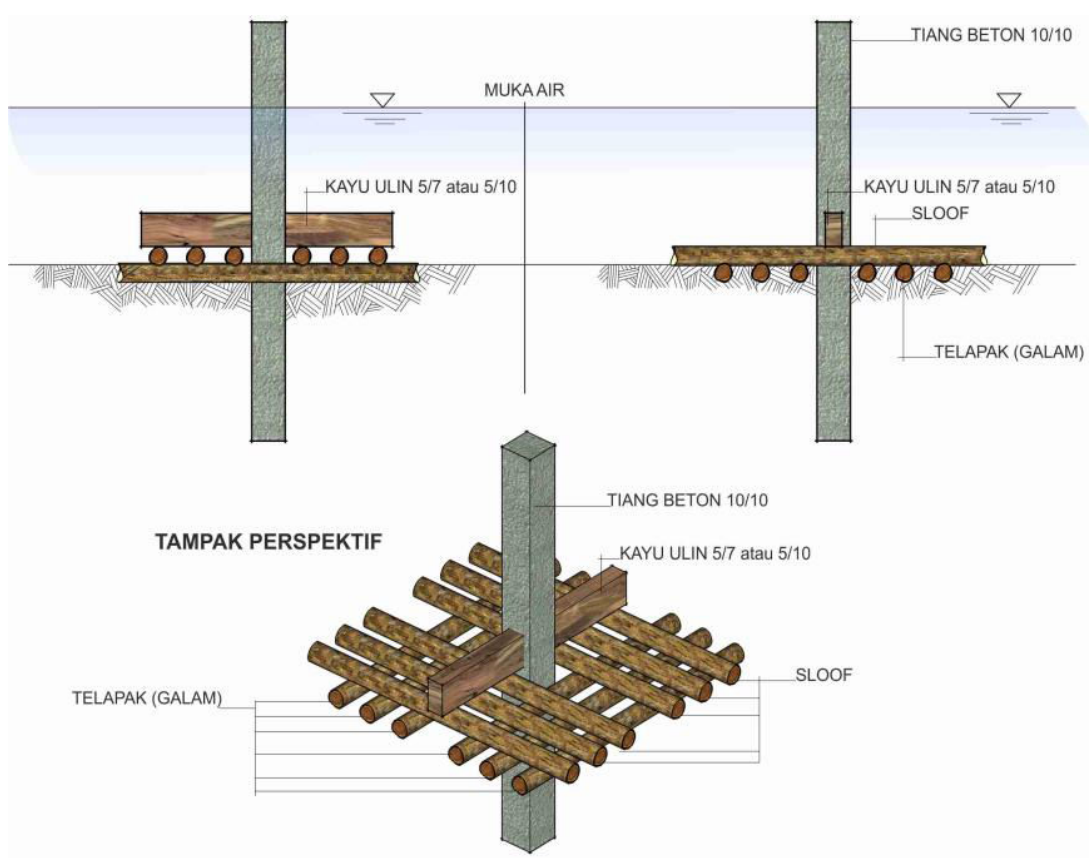

Fig. 2. Alternative kacapuri foundation 3 gelam (Ma'ruf, M.A., etc. 2013)

$$
\text { qult }=2+0,28 \mathrm{qc}(\mathrm{kg} / \mathrm{cm} 2)
$$

where :

$\mathrm{q}_{\mathrm{ult}}=$ Ultimate bearing capacity

$\mathrm{qc}=$ end bearing of CPT

The weight of the alternative foundation and the total weight of the house model is count as a baseline review on the foundation design will be based on the research by The Ministry of Public Work (2015) [2] using the model of Dayak house Huma Hai as shown in Figure 3 to Figure 4. After all the stages are completed then taken the conclusion. 

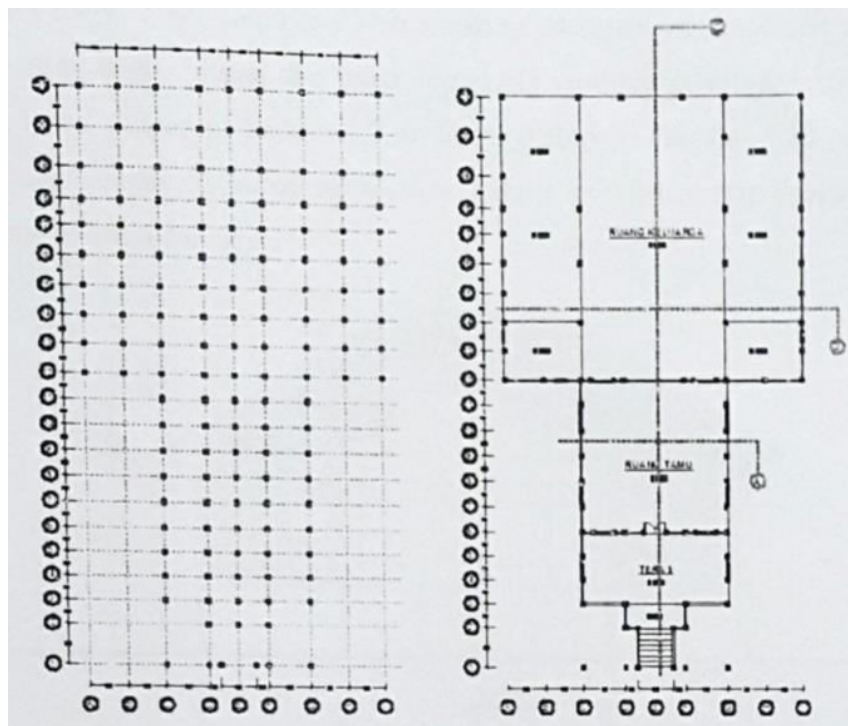

Fig. 3. Column and floor layout of Dayak house Huma Hai (The Ministry of Public Work 2015)

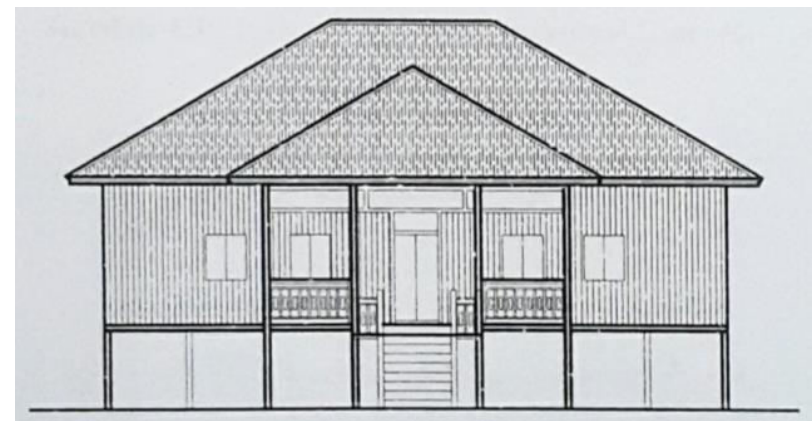

Fig. 4. Front View of Dayak house Huma Hai (The Ministry of Public Work 2015)

\section{Result and discussion}

From the CPT result obtained at the research location which shown in Figure 5. The qc value that is to be used is taken from $1,5 \mathrm{~m}$ depth as shown in Figure 5 . The exact value is $3,5 \mathrm{~kg} / \mathrm{cm}^{2}$. From that value is then put into equation (1). The ultimate bearing capacity then obtains as follow:

$$
\begin{aligned}
& \text { qult }=2+0,28(3,5) \\
& \text { qult }=2,98 \mathrm{~kg} / \mathrm{cm}^{2}=298 \mathrm{kN} / \mathrm{m}^{2}
\end{aligned}
$$




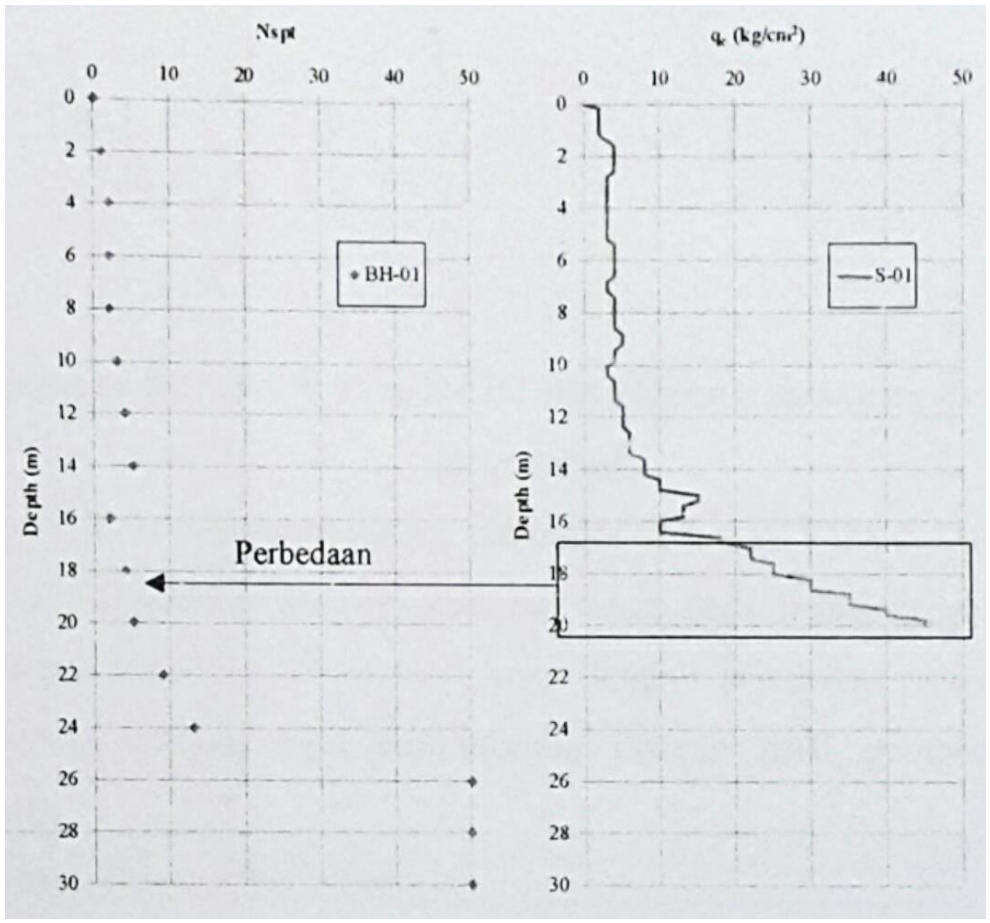

Fig. 5. The Result of SPT and CPT Test (The Ministry of Public Work 2015)

The own weight of the foundation is then calculated based on the volume of each ingredient, ie galam wood, ironwood, and reinforced concrete, with the volume weight of each material can be seen in Table 1 below.

Table 1. The Volume Weight Of Each Material (The Ministry of Public Work 2015)

\begin{tabular}{|c|c|}
\hline Material & $\gamma\left(\mathrm{kN} / \mathrm{m}^{3}\right)$ \\
\hline Ironwood & 9 \\
\hline Gelam Wood & 7 \\
\hline Reinforced concrete & 25 \\
\hline
\end{tabular}

Furthermore, self-calculated as follows:

$$
\begin{array}{ll}
\text { Reinforced concrete } & =0,15 \mathrm{~m} \times 0,15 \mathrm{~m} \times 2 \times 25 \mathrm{kN} / \mathrm{m}^{3}=1,125 \mathrm{kN} \\
\text { Gelam Wood } & =12 \times 6 \mathrm{~m} \times \pi \times 0,04 \mathrm{~m}^{2} \times 7 \mathrm{kN} / \mathrm{m}^{3}=2,534 \mathrm{kN} \\
\text { Ironwood } & =4 \times 0,05 \mathrm{~m}^{2} \times 0,07 \mathrm{~m}^{2} \times 9 \mathrm{kN} / \mathrm{m}^{3}=0,126 \mathrm{kN}
\end{array}
$$

The own weight is then obtained for $4,816 \mathrm{kN}$. For the load to be received the foundation will be calculated based on using the model of Dayak house Huma Hai from the research by The Ministry of Public Work (2015) [2]. The maximum load for the column itself is concluded for $9,93 \mathrm{kN}$ as the result described. 
If the foundation of the house is applied for the alternative kacapuri foundation, then the burden which is to be received by one foundation will still a lot smaller compare to the bearing capacity itself. From the results of the analysis, it can be concluded that the bearing capacity of the soil for the alternative kacapuri foundation is still able to be applied for the simple home building.

\section{Conclusion}

From the analysis results obtained the ultimate bearing capacity of $298 \mathrm{kN} / \mathrm{m} 2$, with the own weight of the alternative foundation of $4,816 \mathrm{kN}$. For the load to be received the foundation will be $9,93 \mathrm{kN}$. Based on the comparison of the bearing capacity of the soil to the building load and the weight of the foundation itself, the safety factor obtained for the foundation is 1.33 , which is still safe. From the results of the analysis, it can be concluded that the bearing capacity of the soil for the alternative kacapuri foundation is still to be applied for a simple home building.

\section{Acknowledgments}

Acknowledgments are given to the Faculty of Engineering, University of Lambung Mangkurat Banjarbaru who has financed the implementation of this research with the scheme of Excellence Research Grant Faculty of Engineering University of Lambung Mangkurat Fiscal Year 2018. Also thanks to The Ministry of Public Work for the data provided.

\section{References}

1. Ma'ruf, M.A., etc.The Alternative Design Of Kacapuri Foundation For Stage Home On Stabilised Peat Soil (Alternatif Desain Pondasi Kacapuri Untuk Rumah Panggung Di Atas Tanah Gambut Yang Distabilisasi). Jurnal Infoteknik Edisi Desember 2013. (2013)

2. The Ministry Of Public Work (Kementerian Pekerjaan Umum). Study on The Technology of Building and Settlement on Traditional Dayak Ngaju Tribe, Sub Analysis on Structure System (Kegiatan Pengkajian Teknologi Bangunan Dan Lingkungan Permukiman Tradisional Suku Dayak Ngaju, Sub Kegiatan Keandalan Sistem Struktur). (2015)

3. Iskandar. Study of Theoritical Bearing Capacity of Kacapuri Foundation (Tinjauan Kapasitas Dukung Teoritis Pondasi Kacapuri). Jurnal Info-Teknik Volume 1 No. 1, Desember 2000 (13-21), (2000)

4. Bowles, J.E., Foundation Analysis And Design, Jakarta: Erlangga. (1997) 